\title{
Sudden Death in Sport Before and After Introduction of the Basic Fitness Test
}

\author{
Lt Col P Lynch, \\ MD, MRCP, RAMC
}

Capt $N$ Ineson, MRCP, RAMC

Capt KP Jones, $M B, B S, R A M C$

Capt A W M Scott, $M B, C h B, R A M C$

Cardiac Department, Queen Elizabeth Military Hospital, Woolwich

SUMMARY: This study examines sudden unexpected deaths in relation to strenuous exercise in the five years following the introduction of the Basic Fitness Test viz: 1978-82 and, by comparison with an identical study of the years 1968-77, shows that the annual exercise associated mortality rate rose from 3.5 per 100,000 before the Basic Fitness Test to 4.75 per 100,000 after its introduction. Sudden unexpected death in relation to strenuous exercise is rare, and its incidence has not importantly changed since the introduction of the Basic Fitness Test.

\section{Introduction}

Sudden unexpected deaths in apparently healthy young men are highly emotive tragedies. When they occur in relation to strenuous exercise there is a widespread tendency to regard exercise as the precipitant. In 1977 the British army introduced the Basic Fitness Test (BFT), essentially a twice yearly run of three miles in under $\mathbf{3 0}$ minutes as a compulsory part of training. This paper examines the mortality associated with strenuous exercise before and after the introduction of the BFT.

\section{Methods}

The Central Medical Envelope (F Med 29) held at Stats G(4), Ministry of Defence contains complete and detailed medical records of all serving personnel. The records of all British Army males who died in the five years from 1978 to 1982 were examined to discover those dying suddenly and unexpectedly within 24 hours of strenuous exercise and compared with an identical study of the years $1968-77^{1}$.

In all there were 958 deaths in the five years and records were available in 944 cases $(98.5 \%)$. Sudden unexpected death is defined as death occurring instantaneously or within 24 hours of the onset of symptoms in apparently healthy men and in whom there was no apparent cause of death. Trauma and heat illness are thus excluded. The validity of the study depends upon the documentation of strenuous exercise in relation to death and, while this is open to error, the dramatic nature of the event suggests that the association is likely to be recorded in most cases.
Moreover, since the methodology for the years 1978-82 is identical to that for 1968-77, comparison of the two periods is likely to be valid.

\section{Results}

In the 10 years prior to the BFT there were 56 sudden unexpected deaths within 24 hours of strenuous exercise in 1.6 million man-years, giving an annual incidence of 3.5 per 100,000 . In the five years thereafter there were 38 such deaths in 800,000 man-years, an annual incidence of 4.75 per 100,000 . Table I shows the atheromatous, and Table II the non-atheromatous causes of exercise associated deaths in the decade before, and Tables III and IV the same parameters respectively in the five years after the introduction of the BFT.

These data are summarised in Table $\mathrm{V}$.

\section{Discussion}

It is immediately apparent that sudden unexpected death in relation to strenuous exercise is a rare event and that its incidence has not importantly altered since the introduction of the BFT. This introduction coincided with an upsurge of interest in physical exercise generally in the United Kingdom. If the association of strenuous exercise with sudden death were random, and no good evidence has yet been produced to show that it is not, then the increase in time spent exercising would be sufficient to cause the slight increase in mortality.

The contribution of the BFT itself is difficult to evaluate; only two fatalities were recorded on the test. However while deaths associated with other exercises 
Table I

Atheromatous causes of sudden death. 1968-77

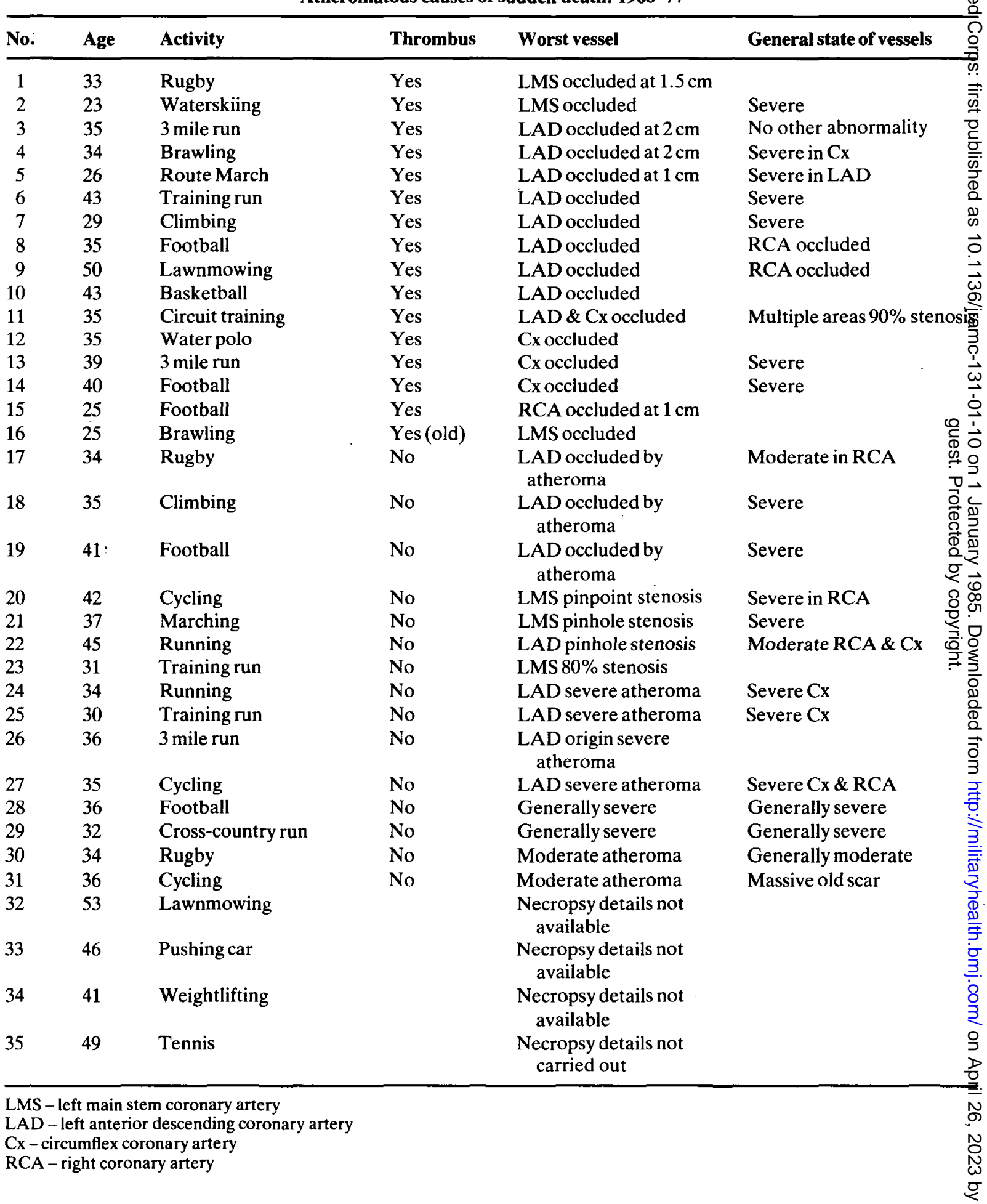


Table II

Non-atheromatous causes of sudden death. 1968-77

\begin{tabular}{|c|c|c|c|}
\hline No & Age. & Activity & Cause of death \\
\hline 1 & 22 & Loading truck & SAH - right middle cerebral artery aneurysm \\
\hline 2 & 35 & Carrying friend & SAH - left anterior cerebral artery aneurysm \\
\hline 3 & 26 & Brawling & $\mathrm{SAH}-$ posterior communicating artery aneurysm \\
\hline 4 & 30 & Marching & $\mathrm{SAH}-$ no aneurysm found at post mortem \\
\hline 5 & 15 & Brawling & SAH - no aneurysm found at post mortem \\
\hline 6 & 21 & Football & SAH-no necropsy \\
\hline 7 & 31 & Football & SAH-no necropsy \\
\hline 8 & 53 & Sexual intercourse & SAH-no necropsy \\
\hline 9 & 29 & Electrocuted while changing light bulbs & SAH-no necropsy \\
\hline 10 & 19 & Pushing vehicle & SAH-no necropsy \\
\hline 11 & 20 & Sprinting & Distal coronary artery atresia \\
\hline 12 & 17 & Unspecified & Hypoplastic coronary arteries and heart \\
\hline 13 & 20 & Physical training & $\begin{array}{l}\text { Ectopic origin of left coronary artery from right } \\
\text { coronary cusp }\end{array}$ \\
\hline 14 & 19 & 3 mile run & $\begin{array}{l}\text { Ectopic origin of left coronary artery from right } \\
\text { coronary cusp }\end{array}$ \\
\hline 15 & 35 & Unspecified & $\begin{array}{l}\text { Aortic dissection in patient with undiagnosed } \\
\text { Marfan's syndrome }\end{array}$ \\
\hline 16 & 17 & 7-a-side rugby & Myopericarditis with normal coronary arteries \\
\hline 17 & 19 & Running & Endocarditis with normal coronary arteries \\
\hline 18 & 21 & 'Training run' & $\begin{array}{l}\text { Bronchopneumonia with normal coronary } \\
\text { arteries. Myocardial histopathology report } \\
\text { not available }\end{array}$ \\
\hline 19 & 29 & Hockey & $\begin{array}{l}\text { No cause found. Normal coronary arteries. } \\
\text { Myocardial histology not available }\end{array}$ \\
\hline 20 & 19 & 10 mile march & $\begin{array}{l}\text { No cause found. Normal coronary arteries and } \\
\text { myocardial histology }\end{array}$ \\
\hline 21 & 19 & 4 mile run & $\begin{array}{l}\text { No cause found. Normal coronary arteries and } \\
\text { myocardial histology }\end{array}$ \\
\hline
\end{tabular}

SAH = subarachnoid haemorrhage

Table III

Atheromatous causes of sudden death. 1978-82

\begin{tabular}{|c|c|c|c|c|c|}
\hline No. & Age & Activity & Thrombus & Worst vessel & General state of coronary arteries \\
\hline 1 & 29 & Jogging & Yes & RCA occluded at $2 \mathrm{cms}$ & $\begin{array}{l}\text { LAD almost occluded in middle third, } \\
\text { Cx narrowed to a slit }\end{array}$ \\
\hline 2 & 47 & Badminton & Yes & RCA occluded & LAD $60 \%$ stenosis \\
\hline 3 & 33 & BFT & Yes & Cx occluded & $\begin{array}{l}\text { Hypoplastic LCA with moderate } \\
\text { atheroma in LAD, RCA large calibre, } \\
\text { patent }\end{array}$ \\
\hline 4 & 29 & BFT & Yes & RCA occluded & $\begin{array}{l}\text { Hypoplastic } \mathrm{Cx} \text { and } \mathrm{LAD}(75 \% \\
\text { reduction in calibre) }\end{array}$ \\
\hline 5 & 38 & Jogging & Yes & RCA occluded & LAD almost occluded by atheroma \\
\hline 6 & 36 & Football & No & Old occlusion LAD & RCA pinhole stenosis, Cx severe \\
\hline 7 & 28 & Football & No & LAD less than pinhole & RCA $70 \%$ stenosis at $1.5 \mathrm{cms}$ \\
\hline
\end{tabular}




\begin{tabular}{|c|c|c|}
\hline 8 & 35 & 3 mile run \\
\hline 9 & 29 & Loading stores \\
\hline 10 & 38 & Running \\
\hline 11 & 33 & Running \\
\hline 12 & 41 & Running \\
\hline 13 & 34 & 2 mile run \\
\hline 14 & 43 & Jogging \\
\hline 15 & 26 & Football \\
\hline 16 & 42 & Basketball \\
\hline 17 & 36 & Jogging \\
\hline 18 & 34 & Hockey \\
\hline 19 & 39 & Hockey \\
\hline 20 & 37 & Running \\
\hline
\end{tabular}

RCA severe stenosis

Cx almost occluded

LMS severe calcified stenosis at $1 \mathrm{~cm}$

RCA severely narrowed at $2 \mathrm{cms}$

LAD grossly narrow at $1 \mathrm{~cm}$

Generally severe

Generally severe

Severe ostial stenosed

Both ostia stenoses

Ill defined

No data

No data

No data
Severe atheroma of $C x$ and LAD

LAD not found, RCA normal'

RCA severely stenosed at $3 \mathrm{cms}$, LAD grossly stenosed

LAD severely narrowed at $2 \mathrm{cms}$, smaller plaque in $\mathrm{Cx}$ at $1 \mathrm{~cm}$

Patchy atheroma throughout

All 3 CA's show well marked atheroma

Severe patchy occlusions in the main stems, extensive myofibrosis

Both CA's show pinpoint stenoses in several places

$C x$ and LAD narrowed and calcified

Fresh mid septum

Death recorded as due to CHD

Death recorded as due to $\mathrm{CHD}$

Death recorded as due to CHD

RCA - right coronary artery

LAD - left anterior descending coronary artery

LMS - left main stem coronary artery

$\mathrm{Cx}$ - circumflex coronary artery

BFT - basic fitness test

$\mathrm{CHD}$ - coronary heart disease

Table IV

Non-atheromatous causes of sudden death. 1978-82

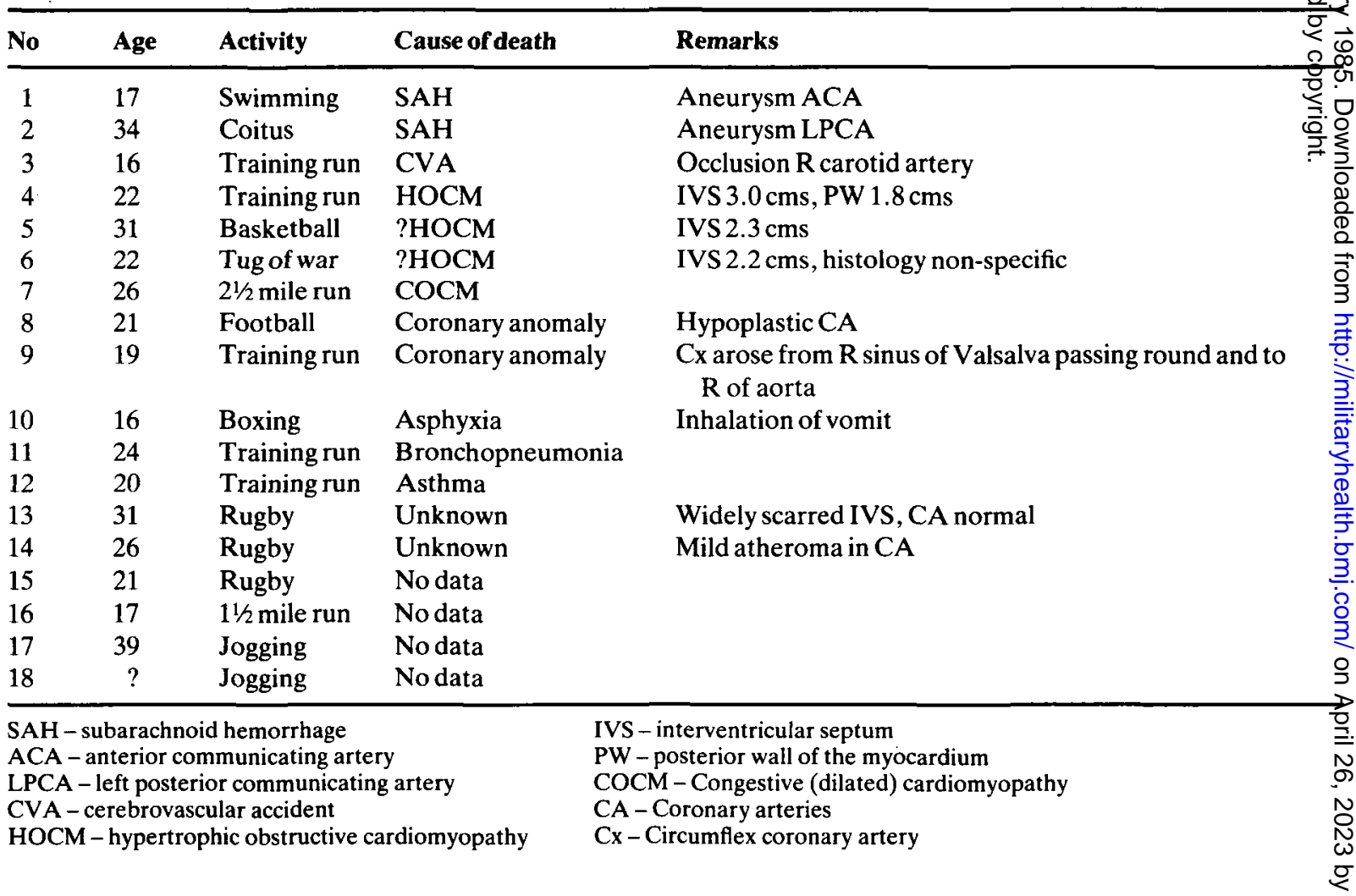


Table V

Summary of Deaths Associated with Running

\begin{tabular}{lcc}
\hline Pre 1977 & Number & $\begin{array}{c}\text { Rate per 100,000 } \\
\text { man years }\end{array}$ \\
\hline $\begin{array}{l}\text { Associated with Running } \\
\text { Associated with other } \\
\text { Exercise }\end{array}$ & 15 & 0.94 \\
\hline Total & 41 & 2.56 \\
\hline Post 1977 & 56 & 3.50 \\
\hline $\begin{array}{l}\text { Associated with Running } \\
\text { Associated with other } \\
\text { Exercise }\end{array}$ & 21 & 2.62 \\
\hline Total & 17 & 2.12 \\
\hline
\end{tabular}

have declined marginally from 2.56 per 100,000 manyears to 2.12 per 100,000 man-years, the increase in deaths associated with running from 0.94 per 100,000 man-years to 2.62 per 100,000 man-years, is probably due to the increased interest in jogging in the Army, which has followed civilian trends and no doubt been reinforced by the introduction of the BFT.

\section{REFERENCE}

1. LYNCH, P. Soldiers, sport and sudden death. Lancet 1980; 1: 1253-7.

\section{TAX RELIEF - SUBSCRIPTION TO THE JOURNAL OF THE ROYAL ARMY MEDICAL CORPS}

This body has been approved for the purposes of Section 192 Income and Corporation Taxes Act 1970 (formerly Section 16 Finance Act 1958) and that the whole of the annual subscription paid by a member who qualifies for relief under that section will be allowable as a deduction from his emoluments assessable to Income Tax under Schedule E.

With effect from the year commencing 6 April 1981 a member who is assessable to Income Tax under Schedule $E$ in respect of the emoluments of an office or employment is entitled to a deduction from those emoluments of the whole of the annual subscription which is due and payable by him to the body in the Income Tax year, provided that a. the subscription is defrayed out of the emoluments of the office or employment, and

b. the activities of the society so far as they are directed to qualifying objects are relevant to the office or employment; that is to say, the performance of the duties of the office or employment, or the exercise of the profession concerned, is directly affected by the pursuance of the qualifying objects.

A member of the body who is entitled to the relief should apply to his Tax Office as soon as possible giving details of his subscription and making a claim for the relief due to him. 